mgr inż. Radostaw Miklasz,

dr ini. Szymon Milecki

Instytut Pojazdów Szynowych ,TABOR”

\title{
Modernization of the TEM 2 locomotive bogies with the aim of reducing operational contamination of the environment
}

\begin{abstract}
The paper presents modernization of the TEM2 locomotive bogies with a view to adapt the present construction to higher requirements related to environmental protection. Modernization of the bogies is caused by modernization of the TEM2 locomotive itself. In consequence, a 19D locomotive is designed, that shall fulfill the requirements of relevant technical specifications for interoperability (TSI). Advisability of the bogie modernization is highlighted with consideration of environmental protection requirements. The goal was supported by the examples of other modernization tasks carried out to date in the Institute of Rail Vehicles "Tabor".

The design changes of the bogie subassemblies are presented, that are conducive directly to reduction of environmental pollution during the vehicle operation.

The paper was prepared within the framework of the Applied Research Program 3 No PBS3/B6/33/2015 entitled "Series of modernized six-axis diesel locomotives meeting the requirements of European Union, making use of the locomotives in operation in Poland" implemented by the Institute of Rail Vehicles "Tabor" in Poznań and the Rail Vehicles "PESA" Bydgoszcz JSC.
\end{abstract}

\section{Modernizacja wózków lokomotywy TEM 2 w celu zmniejszenia zanieczyszczenia eksploatacyjnego środowiska}

\begin{abstract}
$W$ artykule przedstawiono modernizację wózków lokomotywy TEM2 w zakresie dostosowania obecnej konstrukcji do zwiększonych wymagań ochrony środowiska. Modernizacja wózków jest zwiqzana z modernizacja lokomotywy TEM2 W wyniku modernizacji powstanie lokomotywa 19D spetniajaca wymogi odpowiednich specyfikacji technicznych interoperacyjności (TSI).

Opisano celowość modernizacji wózków w świetle wymagań ochrony środowiska. Cel zostat poparty przykladami z innych modernizacji wykonywanych do tej pory w Instytucie Pojazdów Szynowych , Tabor”.

Przedstawiono zmiany konstrukcyjne w podzespołach wózka, które maja bezpośredni wplyw na zmniejszenie zanieczyszczenia środowiska podczas eksploatacji pojazdu.

Artykut powstat w ramach realizowanego projektu Programu Badań Stosowanych $3 \mathrm{nr} \mathrm{Nr}$ PBS3/B6/33/2015 pt. ,,Platforma zmodernizowanych spalinowych lokomotyw 6-osiowych spetniajacych wymagania Unii Europejskiej z wykorzystaniem lokomotyw eksploatowanych w kraju” wykonanego przez Instytut Pojazdów Szynowych ,Tabor” w Poznaniu i Pojazdy Szynowe ,PESA” Bydgoszcz S.A.
\end{abstract}

\section{WPROWADZENIE}

Przeprowadzona analiza efektywności modernizacji wszystkich spalinowych lokomotyw sześcioosiowych w oparciu o analizy cyklu trwałości LCC wykazała, że pełną efektywność i ekonomiczne uzasadnienie zostanie osiagnięte $\mathrm{w}$ przypadku jednoczesnej modernizacji platformy lokomotyw obejmujących lokomotywę liniową serii ST44 (typu M62) i manewrową serii SM48 (typu TEM2), ponieważ jest ich największa ilość w

\section{INTRODUCTION}

Analysis of effectiveness modernization of all the sixaxis diesel locomotives based on the life cycle cost (LCC) has shown that full efficiency and economic justification may be achieved in the case of simultaneous modernization of the series of the locomotives, including the line ST44 locomotive (of M62 type) and the SM48 shunter (of TEM2 type). This is because of their number in operation which is the largest and, 
eksploatacji a ponadto zostały zabudowane na jednym podwoziu obejmującym zarówno ostoję jak i układy biegowe (wózki). Modernizacja dotyczy wszystkich najważniejszych węzłów i układów [1].

Lokomotywy spalinowe TEM2 (ros. TЭM2 - skrót od spalinowa lokomotywa manewrowa $\mathrm{z}$ przekładnią elektryczna) produkowane są od 1960 roku w Briańsku i Ługańsku w ZSRR.

Konstrukcja opiera się na rozwiązaniach amerykańskiej lokomotywy ALCO RSD-1 z lat 40., która dostarczana była do ZSRR w ramach pomocy lend-lease. Lokomotywy te przystosowane są do pracy na torach o szerokości $1435 \mathrm{~mm}$ lub $1520 \mathrm{~mm}$.

Czas eksploatacji tych lokomotyw dochodzi już do 40 lat i na dzień dzisiejszy nie spełniają one wymagań stawianych przez większość użytkowników nastawionych na efektywne gospodarowanie.

Analizując stan techniczny i parametry lokomotyw serii TEM2 pod kątem realizacji koniecznych zmian organizacyjnych i zadań przewozowych, najbardziej ekonomicznie uzasadnioną decyzją jest przeprowadzenie ich modernizacji. Oczekiwanym najważniejszym celem modernizacji będzie poprawa parametrów technicznych i eksploatacyjnych zrealizowanych poprzez:

- spełnienie wymogów określonych aktualnymi normami i kartami UIC, PN, BN i wewnętrznymi zarządzeniami

- $\quad$ poprawę efektywności wykorzystania oraz zmniejszenie kosztów utrzymania $\mathrm{m}$. in. poprzez:

- umożliwienie diagnostyki oraz współpracy $\mathrm{z}$ informatycznymi systemami wspomagającymi zarządzanie eksploatacją i utrzymaniem lokomotyw

- korzystną zmianę DSU - wydłużenie przebiegów (okresów) międzyprzeglądowych i międzynaprawczych, zmniejszenie pracochłonności poszczególnych czynności przeglądowonaprawczych

- poprawę niezawodności lokomotyw i zwiększenie wskaźników gotowości technicznej

- zmniejszenie zużycia części i materiałów eksploatacyjnych

- poprawę bezpieczeństwa ruchu i warunków pracy maszynistów

- eliminację szkodliwych materiałów z lokomotyw.

Poziom techniczny zmodernizowanych lokomotyw, zwłaszcza w odniesieniu do ich walorów trakcyjnych, komfortu pracy maszynistów i personelu obsługi oraz bieżących kosztów eksploatacji, utrzymania i napraw będzie odpowiadał najnowszym standardom lokomotyw aktualnie modernizowanych w takich krajach jak Austria, Niemcy, Czechy i Francja. furthermore, they are designed based on a common chassis, inclusive of the frame and the bogies. Modernization involves all the most important nodes and systems [1].

Production of the TEM2 diesel locomotives (Russian TЭM2 - abbreviation of diesel shunter provided with electrical transmission) began in 1960 in Briańsk and Ługańsk in USSR and lasts until to-day.

The design is based on the solution of the American ALCO RSD-1 locomotive from the 40-ties, delivered to the USSR within the framework of the lend-lease help. The locomotives are designed to run on the $1435 \mathrm{~mm}$ and $1520 \mathrm{~mm}$ gauge tracks.

Lifetime of these locomotives reaches 40 years and today they do not meet the requirements imposed by most of the operators aiming at efficient management. Analysis of technical condition and parameters of the TEM2-series locomotives, with consideration of necessary organizational changes and transport demands, gives evidence that modernization of the locomotives is the most economically reasonable choice. The most important objective of the modernization consists in improvement of the technical and operational parameters, achieved by:

- fulfilling the requirements stipulated by current UIC, PN, BN standards and charts, as well as internal directives;

- improvement of effectiveness of the use and reduction of maintenance cost, among others by:

- enabling diagnostics and cooperation with computer systems aiding the operational management and maintenance of the locomotives;

- advantageous change in Rolling Stock Maintenance Records (RSMR) extension of mileage (period) between overhauls, reduction of labour demand in particular overhaul $\&$ repair operations;

o improvement of reliability and technical readiness factors of the locomotives;

$\circ$ reduction of wear of the parts and consumables;

- improvement of rail traffic safety and working conditions of the train drivers;

- elimination of harmful materials released from the locomotives.

The technical state of the modernized locomotives, particularly in terms of their traction characteristics, comfort of the train drivers and staff, current operational, maintenance and repair costs, shall comply with the latest locomotive standards currently modernized in such countries as Austria, Germany, Czech Republic and France. 
Konstrukcja i parametry lokomotyw po modernizacji muszą spełniać wymogi odpowiednich specyfikacji technicznych interoperacyjności (TSI), obowiązujących $\mathrm{w}$ dniu rozpoczęcia projektowania oraz norm i przepisów wyszczególnionych w specyfikacjach TSI. W zakresie wymagań nieobjętych odnośnymi specyfikacjami TSI obowiązują aktualne ogólne regulacje prawne. W zagadnieniach otwartych w specyfikacjach TSI obowiązują krajowe regulacje lub rozwiązania zaproponowane przez Wykonawcę, które spełniają wymagania zasadnicze zawarte w dyrektywie Parlamentu Europejskiego i Rady Unii Europejskiej.

\section{CEL MODERNIZACJI}

Modernizacja wózków dla zmodernizowanej platformy dwóch typów lokomotyw obejmuje zmiany w układach wózka:

- zmiana w zakresie prowadzenia zestawów kołowych

- poprawa szczelności osłony przekładni

- zwiększenie trwałości obręczy

- poprawa trwałości silników trakcyjnych.

\section{MIEJSCA POWSTAWANIA ZANIECZYSZ- CZEŃ ŚRODOWISKA}

W każdym z układów wózka wymienionych powyżej poddanych modernizacji szczególne znaczenie ma ochrona środowiska. Ochrona środowiska nastawiona jest na zmniejszenie zanieczyszczenia produktami eksploatacyjnymi występującymi w tych układach.

Do tej pory w lokomotywie TEM2 wykorzystującej wózki w swej budowie zbliżone wózków lokomotywy ST44 (zmieniony w zasadzie jest tylko układ hamulca) zastosowane sposoby zmniejszenia zużycia eksploatacyjnego podzespołów wózka były związane ze zmniejszeniem współczynnika tarcia przez zastosowanie materiałów ropopochodnych.

$\mathrm{W}$ tabeli 1 oraz na rys. 1 przedstawiono punkty smarowania wózka lokomotywy.
The design and parameters of the locomotives after modernization must fulfill the requirements of relevant technical specifications for interoperability (TSI) in force on the day of starting the design process, as well as the standards and regulations provided by the TSI specifications.

What concerns the requirements not covered by the TSI specifications the general legal regulations are applicable. In case of the problems covered by the TSI specifications the national provisions or the solutions proposed by the Contractor are in force that meet the essential requirements of the directive of the European Parliament and the Council of European Union.

\section{OBJECTIVE OF THE MODERNIZATION}

Modernization of the bogies of two considered locomotives consists in the following changes in the bogies:

- change of the wheel set guidance

- improvement of tightness of the gear shield;

- increase in wheel band durability;

- improvement of durability of the traction engines.

\section{LOCATIONS OF THE POLLUTION RELEASE}

For each of the above bogie systems subjected to modernization the environment protection is of particular meaning. The environment protection is aimed at reduction of contamination with the consumables used in these systems.

In case of the TEM2 locomotive, the bogie design of which is similar to the one of ST44 locomotive (except for the brake system), the method of wear and tear reduction of the bogie subassemblies consisted to date only in reduction of the friction coefficient by the use of petroleum materials.

Table 1 and Fig. 1 present lubrication points of the locomotive bogie.

Smarowanie wózka lokomotywy serii ST44 (tożsame z lokomotywą TEM2) [2] Tabela 1

\begin{tabular}{|c|c|c|c|}
\hline Lp. & \multicolumn{2}{|c|}{ Miejsce smarowania } & Gatunek oleju lub smaru \\
\hline 1. & \multicolumn{2}{|c|}{ łożyska zawieszenia silnika trakcyjnego } & olej osiowy U (olej osiowy L i Z) \\
\hline 2. & \multicolumn{2}{|c|}{ wspornik zawieszenia silnika trakcyjnego } & smar maszynowy 2 (ŻRO) \\
\hline \multirow{2}{*}{3.} & \multirow{2}{*}{ czop skrętu } & powierzchnie trące & olej osiowy U (olej osiowy L i Z) \\
\hline & & uszczelnienie smarowe gniazda & smar maszynowy 2 (I-ŁZ) \\
\hline 4. & \multicolumn{2}{|c|}{ łożyska toczne silnika trakcyjnego } & ŁT4S3 (ŻRO) \\
\hline 5. & \multicolumn{2}{|c|}{ przekładnia osiowa } & latem KZE-L, zimą KZE-Z (olej osiowy L i Z) \\
\hline \multirow{3}{*}{6.} & \multirow{3}{*}{$\begin{array}{l}\text { łożyska } \\
\text { toczne osi } \\
\text { zestawów } \\
\text { kołowych }\end{array}$} & prowadnice łożysk & olej osiowy U (olej osiowy L i Z) \\
\hline & & $\begin{array}{lll}\text { kadłub } & \text { oporowy } & \text { przesuwu } \\
\text { poprzecznego osi } & \end{array}$ & Superol CB SAE-40 (M14W2) \\
\hline & & kadłub łożysk & ŁT4S3 (I-ŁZ) \\
\hline 7. & \multicolumn{2}{|c|}{ dźwignie hamulcowe wózków } & smar maszynowy 2 lub ŁT43 (ŻRO) \\
\hline \multirow{2}{*}{8.} & \multicolumn{2}{|c|}{ sworznie wieszaków resorowych (sworzeń-tulejka) } & Superol CB SAE-40 (M14W2) \\
\hline & \multicolumn{2}{|c|}{ resory piórowe } & smar grafitowany (USsA) \\
\hline 9. & \multicolumn{2}{|c|}{ ślizgi bocznego podparcia pudła } & olej osiowy U (olej osiowy L i Z) \\
\hline 10. & \multicolumn{2}{|c|}{ cylindry hamulcowe } & smar hamulcowy Z (ŻRO) \\
\hline
\end{tabular}


Lubrication of the bogie of ST44 locomotive (the same as for TEM2 locomotive) [2]

\begin{tabular}{|c|c|c|c|}
\hline In & \multicolumn{2}{|c|}{ Lubrication point } & Oil or lubricant type \\
\hline 1. & \multicolumn{2}{|c|}{ bearings of the traction engine mounting } & axle oil $\mathrm{U}$ (axle oils L and Z) \\
\hline 2. & \multicolumn{2}{|c|}{ bracket of the traction engine mounting } & machine grease 2 (ŻRO) \\
\hline \multirow{2}{*}{3.} & \multirow{2}{*}{ bogie pivot } & friction surfaces & axle oil U (axle oils L and Z) \\
\hline & & lubricated seal of the socket & machine grease 2 (I-ŁZ) \\
\hline 4. & \multicolumn{2}{|c|}{ rolling bearings of the traction engine } & ŁT4S3 (Z̈RO) \\
\hline 5. & \multicolumn{2}{|l|}{ axle gear } & in Summer KZE-L, in Winter KZE-Z (axle oils L and Z) \\
\hline \multirow{3}{*}{6.} & \multirow{3}{*}{$\begin{array}{l}\text { bearings of } \\
\text { the wheel set } \\
\text { axles }\end{array}$} & bearing guides & axle oil U (axle oils L and Z) \\
\hline & & stop casing of axle lateral shift & Superol CB SAE-40 (M14W2) \\
\hline & & casing of the bearings & ŁT4S3 (I-ŁZ) \\
\hline 7. & \multicolumn{2}{|c|}{ brake levers of the bogies } & machine grease 2 or $Ł T 43(\dot{Z} R O)$ \\
\hline \multirow{2}{*}{8.} & \multicolumn{2}{|c|}{ bolts of the leaf spring hangers (bolt-sleeve) } & Superol CB SAE-40 (M14W2) \\
\hline & \multicolumn{2}{|c|}{ leaf springs } & graphite grease (USsA) \\
\hline 9. & \multicolumn{2}{|c|}{ slides of lateral railcar body support } & axle oil U (axle oils L and Z) \\
\hline 10. & \multicolumn{2}{|c|}{ brake operating cylinders } & brake lubricant Z (ŻRO) \\
\hline
\end{tabular}

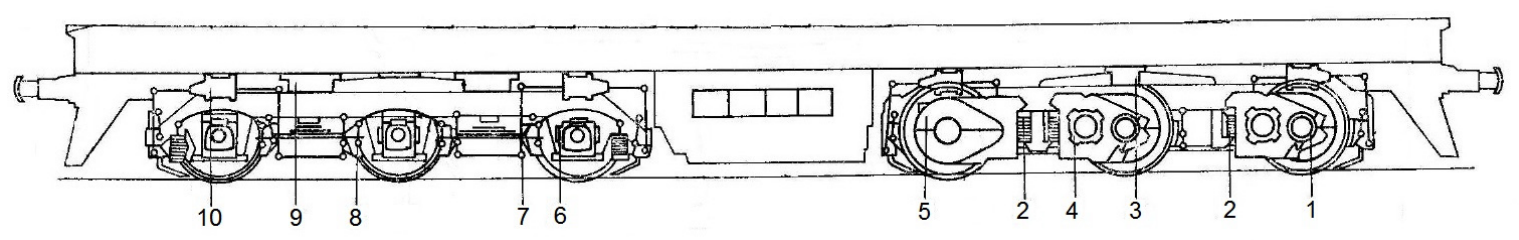

Rys. 1. Miejsca smarowania wózka TEM2 [2].

Fig. 1. Lubrication points of the TEM2 bogie [2]

Do newralgicznych miejsc smarowania wózka lokomotywy TEM2 mających bezpośredni wpływ na zanieczyszczenie środowiska, na szlaku kolejowym należą:

1. Przekładnia osiowa,

2. Prowadnice łożysk (ślizgi prowadzenia widłowego maźnic).

Pozostałe miejsca smarowania wózka powodują mniejsze narażenie środowiska naturalnego na zanieczyszczenia, ponieważ materiały ropopochodne używane do smarowania są aplikowane $w$ miejscach $z$ reguły zabezpieczonych przed przedostaniem się tych produktów do środowiska naturalnego (są to punkty obsługowe pojazdów).

\section{MODYFIKACJA USZCZELNIENIA PRZE- KLADNI OSIOWEJ}

Przekładnia osiowa znajduje się w osłonie przymocowanej śrubami do kadłuba silnika trakcyjnego.

Osłona stanowi jednocześnie zbiornik dla smaru przekładniowego. W górnej jej części znajduje się wlew oleju, a w dolnej - otwór umożliwiający kontrolę poziomu oleju. Osłona przekładni, w której zamontowane jest uszczelnienie, wykonana jest z blachy. Podczas eksploatacji poddawana jest nieustannym drganiom o różnej częstotliwości i przyspieszeniu. Powoduje to silne odkształcenia jej elementów. Uszczelnienie przekładni osiowej, dla tego wózka, jest szczególnie trudnym elementem do wykonania. Do tej pory wykonane jest przez zastosowanie przyspawanych pierścieni $\mathrm{z}$ kształtem umożliwiającym zamontowanie pierścieni filcowych, rys. 2 (widok III).
Among sensitive lubrication points of the TEM2 locomotive bogie that directly affect the environment quality there are:

1. the axle gear;

2. the bearing guides (axle guard liners).

The other lubrication points of the bogie initiate lower hazard to the natural environment, since the petroleum products used for this purpose are applied to the points that are usually protected against their uncontrolled entrance to the natural environment (these are the service points).

\section{MODIFICATION OF THE AXLE GEAR SEAL}

The axle gear is housed in a casing screwed to the traction engine body. The casing serves, at the same time, as a gear grease reservoir. The oil filler is located in its upper part while the bottom part is provided with an opening allowing to check the oil level. The gear casing clamping the seal is made of metal sheet. During operation it is subjected to permanent vibrations of various frequencies and accelerations. This gives rise to high deformation of its parts. In consequence, it is particularly difficult to design the axle gear sealing of the bogie. The sealing is made to date with the use of welded rings having the shape allowing for fixing the felt rings, Fig. 2, (View III).

Drawback of the sealing lies in the fact that the felt ring contacting with the contaminated air occurring in the vicinity of the bogie absorbs over time the dust and sand. In consequence, the sealing ring loses its elastic properties, causing leakage. In result, the gear grease flows out from the sealing area, since the heated grease has a semi-fluid consistency. 
Takie uszczelnienie ma wadę polegającą na tym, że z biegiem czasu pierścienie filcowe $\mathrm{w}$ kontakcie $\mathrm{z}$ zanieczyszczonym powietrzem znajdującym się w obrębie wózka powoduje jego nasączenie pyłem i piaskiem. W konsekwencji pierścień uszczelniający traci swoje elastyczne właściwości, powodując powstawanie nieszczelności. W konsekwencji tego $\mathrm{z}$ miejsc uszczelnionych zaczyna wypływać smar przekładniowy, który po nagrzaniu podczas pracy ma konsystencję gęstego oleju.

Na rys. 2 (widok I) uszczelnienie od strony koła zestawu kołowego jest wykonane przez zastosowanie odrzutnika. Taki rodzaj uszczelnienia powoduje, że po nagrzaniu smaru przekładniowego i zmniejszeniu jego lepkości występuje silne wydostawanie się tego środka na zewnątrz. Zastosowany taki rodzaj zabezpieczenia przez wydostaniem się środka smarnego ma tą zaletę, że może być rodzajem odpowietrzania osłony przekładni.

W ramach modernizacji lokomotywy ST44, wyposażonej w bliźniaczą przekładnię jak na lokomotywie TEM2, prowadzonej przez Instytut Pojazdów Szynowych „Tabor” wykonaliśmy uproszczoną modernizację tych węzłów. Polegała ona na zwiększeniu wysokości pierścienia filcowego oraz wprowadzono dodatkowy pierścień filcowy w miejsce odrzutnika środka smarnego. Wykonano w związku z tym nowe pierścienie uszczelnienia, w których zamontowano pierścienie filcowe oraz zamontowano nowe wyższe pierścienie uszczelniające. Dodatkowo wykonano odpowietrzenie osłony przekładni.

Zabieg konstrukcyjny okazał się częściowym sukcesem. Z biegiem czasu eksploatacji pojawily się nieznaczne wycieki $\mathrm{z}$ miejsc uszczelnionych, przedstawione na rys. 3

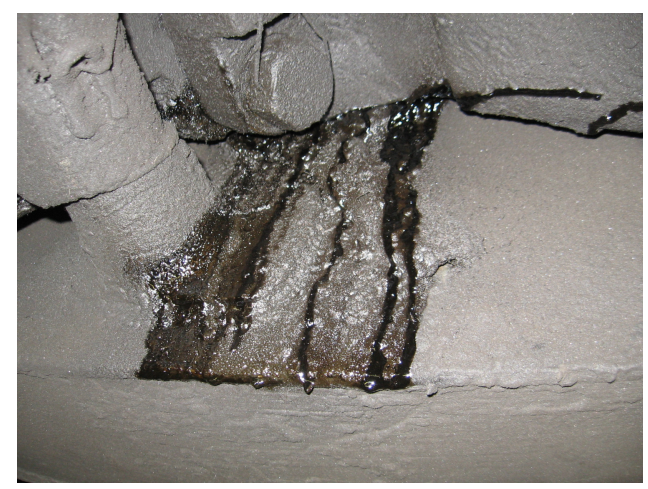

Rys. 3. Wycieki środka smarnego w zmodernizowanym wózku lokomotywy ST44.

Fig. 3. Lubricant leakage in the modernized bogie of the ST44 locomotive

Podczas modernizacji lokomotywy TEM2 do wersji 19D zostały postawione nowe założenia modernizacji przekładni w zakresie jej uszczelnienia.

Należało przyjąć założenia, że na skutek drgań pojawiają się nadmierne odkształcenia przekładni. Rozwiązanie tego węzła powinno opierać się więc na

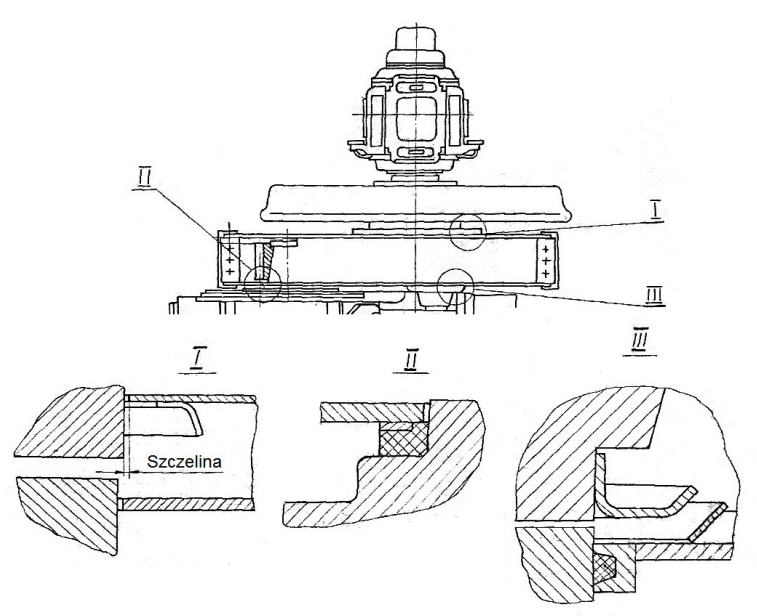

Rys. 2. Uszczelnienie przekładni osiowej w wózkach lokomotywy TEM2.

Fig. 2. Sealing of the axle gear of the TEM2 locomotive bogie

In Fig. 2 (View I) the sealing at the wheel side is provided with oil deflector. Such sealing type causes that once the gear grease is heated its viscosity drops and the grease escapes outside. On the other hand, advantage of such a sealing solution consists in the fact that it may be considered as a kind of a gear housing venting.

As a part of ST44 locomotive modernization made in the Institute of Rail Vehicles "Tabor" a simplified upgrade of some structural nodes has been carried out. The locomotive is provided with the gear very similar to the one of the TEM2. The change consisted in increase of the felt ring height and addition of another felt ring replacing the oil deflector. Therefore, new sealing rings have been fabricated that matched to both felt rings. Additionally, the gear housing venting has been provided.

This solution has been partially successful. After a certain time slight leakage occurred from the sealed area, which is shown in Fig. 3.

In case of modernization of the TEM2 locomotive to 19D version some new assumptions have been adopted with regard to the sealing.

It should be admitted that excessive gear deformation arise in result of vibration. Hence, the solution should provide compensation of the deformation in the place of sealing contact. The MILLER FELPAX CORP. offered help and proposed complete change to the sealing concepts. Instead of unreliable felt rings, which only poorly deform and absorb abrasives from the contaminated air, the seals made of highly elastic material may be used. Their shape enables matching to the sealed part and gear housing shapes. Basic idea of the concept is set out in Fig. 4, while Fig. 5 presents the details of the sealing solution.

Such a seal type should properly compensate the gear deformation during operation and ensure proper contact with the sealed surface. The material used for the seals is resistant to the gear grease. The sealing should be replaced during general overhaul of the gear. 
kompensacji tych odkształceń $\mathrm{w}$ miejscach przylgowych tego uszczelnienia. Z pomoca przyszła firma MILLER FELPAX CORP.. Zaproponowała całkowita zmianę koncepcji uszczelnienia. W miejsce zawodnych podczas eksploatacji pierścieni filcowych, charakteryzujących się małą możliwością odkształcenia $\mathrm{i}$ możliwością absorpcji materiałów ściernych $\mathrm{z}$ zanieczyszczonego powietrza, wprowadzić można uszczelki z materiału wysokoelastycznego o kształcie umożliwiającym dopasowanie się zarówno do kształtu elementu uszczelnianego jak i obudowy przekładni. Koncepcję tego rozwiązania przedstawiono na rys.4. Na rys. 5 przedstawiono szczegóły rozwiązania uszczelnienia.

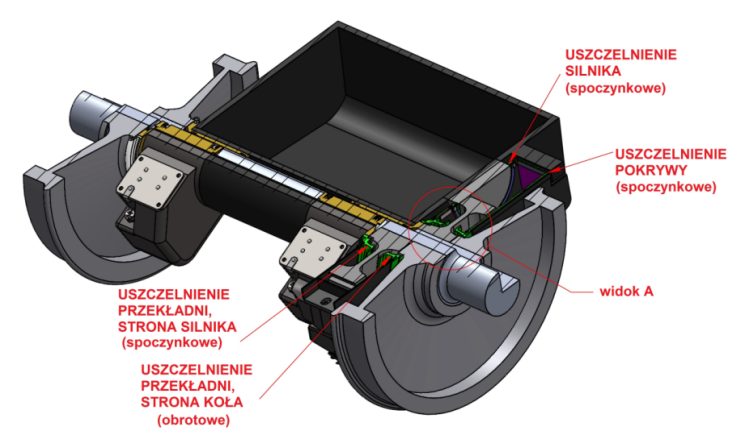

Rys. 4. Miejsca zastosowania zmodernizowanych uszczelnień przekładni [Miller Felpax Corp.] [3].

Fig. 4. Area of application of the modernized gear seals [Miller Felpax Corp.] [3]

Taki rodzaj uszczelnienia powinien zrekompensować zarówno odkształcenia przekładni podczas eksploatacji oraz zapewnić właściwe przyleganie uszczelnienia do powierzchni uszczelnianej. Materiał zastosowany jako uszczelnienie jest odporny na działanie smaru przekładniowego. Wymiana takiego uszczelnienia powinna nastapić podczas naprawy głównej przekładni. Takie rozwiązanie można więc traktować jako bezobsługowe podczas całego okresu eksploatacji.

\section{MODERNIZACJA PROWADZENIA MAŹNIC}

Drugim newralgicznym miejscem powstawania zanieczyszczeń środowiska są prowadnice łożysk (ślizgi prowadzenia widłowego maźnic).

Rama wózka posiada przyspawane do podłużnic widły maźnicze stanowiące jednolitą konstrukcję. Do prowadników wideł przyspawane są ślizgi wykonane $\mathrm{z}$ blachy odpornej na ścieranie, które po ulepszaniu cieplnym mają twardość 285-363 HB. Widły maźniczne są ściagnięte zworami przykręcanymi dwoma śrubami. Zestawy kołowe zamontowane w wózku za pomocą występów w maźnicach współpracują z widłami maźnicznymi.

Do tej pory w celu zmniejszenia szybkości zużywania się elementów współpracujących ze sobą podczas prowadzenia zestawu kołowego używano oleju, który grawitacyjnie przy udziale sznura konopnego doprowadzał środek smarny (olej) do miejsc styku części
Hence, such a solution may be considered as maintenance free for the whole lifetime.

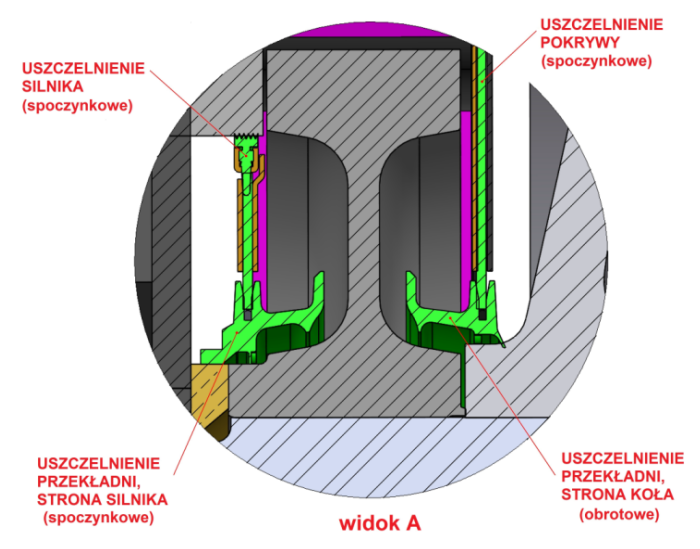

Rys. 5. Szczegół A zmodernizowanego uszczelnienia przekładni [Miller Felpax Corp.] [3].

Fig. 5. Detail A of the modernized gear seals [Miller Felpax Corp.] [3]

\section{MODERNIZATION OF AXLE-BOX GUI- DANCE}

The bearing guides (i.e. axle guard liners) are another sensitive source of the environment pollution.

The bogie frame is provided with axle guards welded to the frame side member, being a single structure. The slides made of abrasion resistant metal sheet are welded to the axle guard guide. Their hardness, after quenching and tempering, is equal to 285-363 HB. The axle guards are held together with pedestal straps bolted with two screws. The wheel sets are mounted in the bogie with the help of pedestal legs co-working with the axle guards.

To date, in order to reduce wearing of the parts interacting during wheel set guiding, an oil was used. It was delivered from the oil tank located in the axle guard body (Fig. 6). The oil flew down by gravitation, via hemp rope, and penetrated to the contact area of the mating parts (i.e. axle guard liners and axle-box liners).

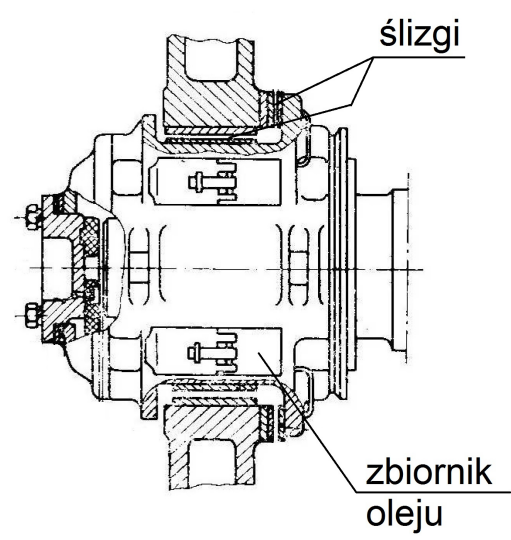

Rys. 6. Rozwiązanie konstrukcyjne prowadzenia zestawu kołowego w wózku lokomotywy TEM2.

Fig. 6. Constructional solution of the wheel set guiding of the TEM2 locomotive bogie 
współpracujących (ślizgów wideł maźnicznych i ślizgów maźnicy). Zbiornik oleju znajdował się w korpusie maźnicy rys. 6

W ramach modernizacji lokomotywy ST44, wyposażonej $\mathrm{w}$ identyczne prowadzenie zestawu kołowego jak na lokomotywie TEM2, prowadzonej przez Instytut Pojazdów Szynowych „TABOR” wykonaliśmy zbiornik w postaci korytka, do zbierania spływającego środka smarnego.

Niedogodnością tego rozwiązania jest oprócz dodatkowego elementu konstrukcyjnego również konieczność cyklicznego opróżniania tego zbiornika. Rozwiązanie konstrukcyjne przedstawiono na rys.7

Ciekawą propozycję przedstawiła ponownie firma MILLER FELPAX CORP. Zaproponowała ona zastosowanie wyłożenia ślizgów w postaci korytka obejmującego swym kształtem $\mathrm{z}$ trzech stron widły prowadzenia maźnicy rys. 8

Materiał użyty na wkładkę jest poliamidem z dodatkiem dwusiarczku molibdenu (MoS2). Dwusiarczek molibdenu jest stałym środkiem smarnym. Para cierna stal - wkładka wideł maźnicznych nie wymaga smarowania. $\mathrm{Z}$ dostępnych wyników badań przeprowadzonych przez producenta tego tworzywa wynika, że dodatkowe smarowanie powoduje zwiększenie zużycia powierzchni ciernych. Spowodowane jest to przyleganiem twardych zanieczyszczeń do zaoliwionych powierzchni ciernych.

Zabudowa wkładek polega na przystosowaniu wideł maźniczych pod względem wymiarowym do zamontowania wkładek. Wstawki montuje się za pomocą śrub do korpusu wideł maźniczych. Wymiary zabudowy pozostają takie same jak dla standardowego prowadzenia wideł maźniczych.

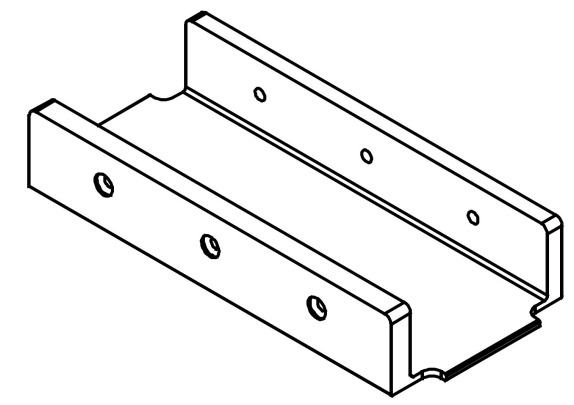

Rys. 8. Widok wkładki wideł maźniczych [Miller Felpax Corp.] [3].

Fig. 8. View of the axle guard insert [Miller Felpax Corp.] [3]

\section{SMAROWANIE OBRZEŻY KÓŁ}

Utrzymanie infrastruktury kolejowej pochłania wysokie nakłady finansowe. Szczególnie drogie w utrzymaniu są odcinki toru o ciasnych łukach oraz w głowicach rozjazdowych. Koszty utrzymania rosną dodatkowo przy używaniu taboru w złym stanie technicznym.

W rzeczywistych warunkach pracy zestawu kołoszyna w miejscu kontaktu występują naprężenia oraz poślizgi wpływające na procesy zachodzące w tym
Further modernization carried out in the Institute of Rail Vehicles "TABOR" concerned the ST44 locomotive, that is provided with wheel set guidance identical to the one of the TEM2 locomotive. In this case a tank in the form of a tray was designed, with a view to collect the grease flowing down. Inconveniences of such a solution include occurrence of an additional structural part and the need of its periodical emptying. The design is shown in Fig. 7.

In interesting solution has been presented by MILLER FELPAX CORP. again. They proposed a liner in the form of a tray, enclosing the axle guard from three sides - Fig. 8.

The material the insert is made of is polyamide with addition of molybdenum disulfide $\left(\mathrm{MoS}_{2}\right)$. Molybdenum disulfide is a grease. The friction pair steel - axle guard insert requires no lubrication. Available results of the research carried out by the manufacturer show that additional lubricating causes more extensive wear of the friction surfaces. This is due to adhesion of hard pollution particles to oiled friction surfaces. In order to assemble the inserts the dimensions of the axle guards must be adjusted accordingly. The inserts are screwed to the axle guard body.

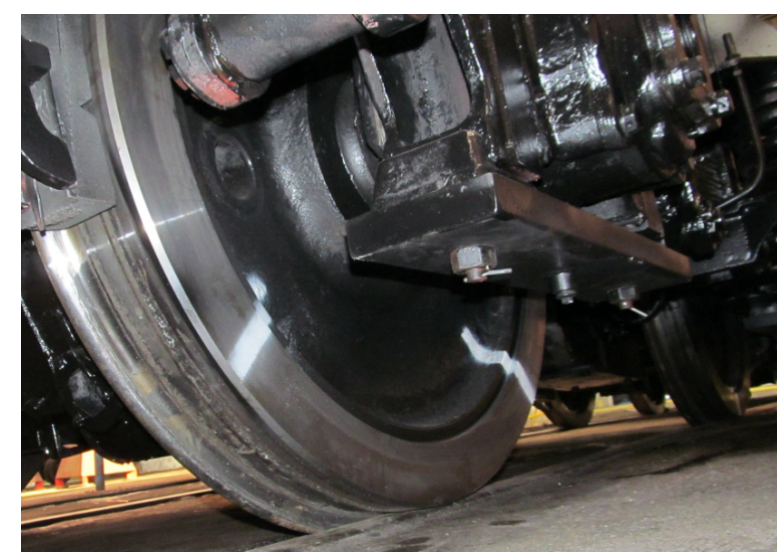

Rys. 7. Zbiornik do zbierania materiału smarnego zamontowany pod korpusem maźnicy.

Fig. 7. The tank design for collecting the lubricant, located under the axle-box body

\section{LUBRICATION OF THE WHEEL FLANGES}

Maintenance of the railway infrastructure involves high expenditures. The narrow bend track sections and switch blades are particularly expensive to maintain. The maintenance costs additionally grow in case of the use of the rolling stock in poor technical condition. Under actual conditions of the wheel-rail pair the stresses and slips occur that affect the processes undergoing in this important area. The contact surface permanently varies, in accordance with many factors of structural and operational kind. Superposition of these impacts contributes to the fact that the problem of longevity of the superficial part of the rail remains unresolved. 
ważnym miejscu. Powierzchnia kontaktu ulega ciagłej zmianie w zależności od wielu czynników zarówno konstrukcyjnych, jak i eksploatacyjnych. W wyniku nakładania się tych czynników problem trwałości warstwy wierzchniej szyn kolejowych, pozostaje nadal nierozwiązany.

Dla poprawienia warunków współpracy koła z szyna, szczególnie w czasie jady taboru kolejowego po łukach o małym promieniu, stosuje się smarowanie miejsc najbardziej narażonych na zużycie ścierne. Przyczynami tego zużycia są naprężenia styczne i normalne występujące w miejscu styku koła z szyną. Naprężenia te osiągają największe wartości w pojazdach trakcyjnych [4].

Zastosowane przy modernizacji wózka smarowanie obrzeży kół jest rozwiązaniem dozującym środek smarny w postaci mgły olejowej na obrzeże koła.

Taki układ w połączeniu z układem sterującym dozowanie środka smarnego powoduje oszczędności w zużyciu środka smarnego dla całego pojazdu.

\section{PODSUMOWANIE}

$\mathrm{Z}$ przeprowadzonych $\mathrm{w}$ artykule analiz rozwiązań konstrukcyjnych stosowanych sposobów modernizacji węzłów w wózku lokomotywy TEM2 zauważyć można, że przy kompleksowej modernizacji można uzyskać zadowalający wpływ na zwiększenie ochrony środowiska.

Przepisy TSI do tej pory nie precyzują wymagań ochrony środowiska dotyczących zanieczyszczenia przestrzeni wokół torowiska w aspekcie przedostawania się do niego produktów eksploatacyjnych stosowanych w wózkach pojazdów trakcyjnych. Należy w związku z tym mieć na uwadze ogólne wytyczne dotyczące ochrony środowiska przedstawione przez producentów poszczególnych materiałów eksploatacyjnych.

Obecnie firmy produkujące materiały eksploatacyjne mające w swej ofercie produkty, które w bezpośredni sposób oddziaływają na środowisko dążą do tego, aby były to produkty biodegradowalne. Dotyczy to w głównej mierze materiałów smarnych użytych w układach smarowania obrzeży kół.

Ochrona środowiska jest również w sposób bezpośredni związana z trwałością poszczególnych układów wózka. Częsta wymiana i naprawa tych układów pociąga za sobą wykonywanie nowych elementów do wymiany. Powoduje to zwiększenie zużycia energii na ich wykonanie. Racjonalne sposoby redukcji zużycia tej energii wpływają w bezpośredni sposób zanieczyszczenie środowiska produktami potrzebnymi do jej wyprodukowania. Niebagatelnego znaczenia nabierają więc zabiegi konstrukcyjne powodujące znaczną redukcję zużycia tych elementów. Zastosowane podczas modernizacji nowe wyłożenie wideł maźniczych przyczynia się wydłużenia okresów między wymianami par ciernych tych elementów.
In order to improve the conditions of wheel/rail mating, particularly on a narrow bend track sections, the areas the most vulnerable to friction wearing are lubricated. The wearing is due to shearing and normal stress arising in the wheel/rail contact. These stresses achieve the highest level in case of traction vehicles [4].

Modernization of the bogie includes lubrication of the wheel flanges supplemented by a device supplying the lubricant to the wheel flange in the form of a properly dosed fog.

Such a system, together with the lubricant dosing device, results in savings of the lubricant consumption in the vehicle as a whole.

\section{SUMMARY}

Analyses of the design solutions related to modernization of the nodes of TEM2 locomotive bogie discussed in the present paper show that such a complex modernization may positively affect the environment protection.

The TSI regulations so far do not precise requirements related to protection of the environment with regard to contamination of the area of the railway subgrade caused by penetration of the consumables used in the traction vehicle bogies. Hence, the general guidelines related to environment protection, formulated by manufacturers of particular consumables should be taken into account.

Today the companies producing the consumables that directly affect the environment status, make efforts to make them biodegradable ones. This concerns mainly the lubricants designed for greasing of the wheel flanges.

Environment protection is also strictly related to durability of particular bogie subassemblies. In order to repair these subassemblies new parts must be manufactured, that requires extra energy. Reasonable methods aimed at reduction of the energy consumption directly decrease pollution of the environment with the substances necessary for its production. Hence, the design endeavours resulting in wear reduction of these parts are of considerable significance. New, modernized lining of the axle guard contributes to extending the intervals between replacing the friction pairs of these parts.

Application of the devices designed for lubrication of wheel flange of the locomotives running on the surveyed lines noticeably extends mileage between wheel reprofiling operations as compared to the locomotives not provided with these devices and operating in equal conditions.

Among particular advantages of wheel lubrication the following may be mentioned:

- savings in consumption of quality steel used for wheels and rails production; 
Zastosowanie urządzeń do smarowania obrzeży kół w lokomotywach kursujących na danych liniach w zauważalnym stopniu poprawia przebiegi między reprofilacjami kół w innych lokomotywach (bez urządzeń smarujących) eksploatowanych w tych samych warunkach.

Do szczególnych zalet $\mathrm{z}$ stosowania smarowania kół należą:

- oszczędność w stosowaniu wysokogatunkowych stali na koła i szyny

- zmniejszenie pracochłonności przy utrzymaniu zastawów kołowych

- oszczędność energii potrzebnej do napędzania pojazdu

- zmniejszenie hałasu

- możliwość stosowania środków biodegradowalnych i to w ograniczonej ilości

- podniesienie bezpieczeństwa przed wykolejeniem.
- reduction of labour demand related to wheelset maintenance;

- savings in energy consumption necessary for vehicle propulsion;

- noise reduction;

- possible use of small amounts of biodegradables;

- higher safety against derailment.

\section{LITERATURA}

[1] Projekt Programu Badań Stosowanych $3 \mathrm{nr} \mathrm{Nr}$ PBS3/B6/33/2015: „Platforma zmodernizowanych spalinowych lokomotyw 6-osiowych spetniajacych wymagania Unii Europejskiej $z$ wykorzystaniem lokomotyw eksploatowanych w kraju"

[2] Domański E., Ożóg Z. „Lokomotywy spalinowe serii ST44" WKiE Warszawa 1984r,

[3] Miller Felpax Corp. Materiaty,

[4] Wójtowicz A., H. Bakowski „, Oszczędności wynikajace ze smarowania obrzeży kót $w$ tukach o różnym promieniu” Technika Transportu Szynowego 2-3/2013. 